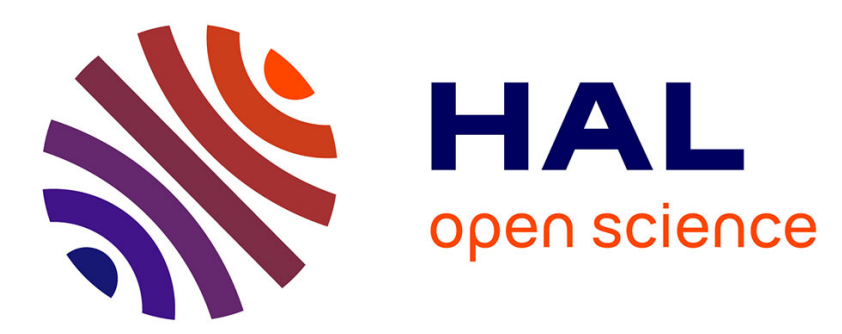

\title{
A simple algorithm to estimate evapotranspiration from DAIS data: Application to the DAISEX campaigns
}

\author{
J.A. Sobrino, M. Gomez, J.C. Jimenez-Munoz, Albert Olioso, Ghani \\ Chehbouni
}

\section{- To cite this version:}

J.A. Sobrino, M. Gomez, J.C. Jimenez-Munoz, Albert Olioso, Ghani Chehbouni. A simple algorithm to estimate evapotranspiration from DAIS data: Application to the DAISEX campaigns. Journal of Hydrology, 2005, 315, pp.117-125. 10.1016/j.jhydrol.2005.03.027 . ird-00425916

\section{HAL Id: ird-00425916 https://hal.ird.fr/ird-00425916}

Submitted on 22 Oct 2009

HAL is a multi-disciplinary open access archive for the deposit and dissemination of scientific research documents, whether they are published or not. The documents may come from teaching and research institutions in France or abroad, or from public or private research centers.
L'archive ouverte pluridisciplinaire HAL, est destinée au dépôt et à la diffusion de documents scientifiques de niveau recherche, publiés ou non, émanant des établissements d'enseignement et de recherche français ou étrangers, des laboratoires publics ou privés. 


\title{
A simple algorithm to estimate evapotranspiration from DAIS data: Application to the DAISEX campaigns
}

\author{
J.A. Sobrino ${ }^{\mathrm{a}, *}$, M. Gómez ${ }^{\mathrm{a}}$, J.C. Jiménez-Muñoz ${ }^{\mathrm{a}}$, A. Olioso ${ }^{\mathrm{b}}$, G. Chehbouni ${ }^{\mathrm{c}}$ \\ ${ }^{a}$ Department of Thermodynamics, Faculty of Physics, University of Valencia, 50 Dr Moliner, 46100 Burjassot, Spain \\ ${ }^{\mathrm{b}}$ INRA Bioclimatologie, Domaine Saint-Paul, Avignon, France \\ ${ }^{\mathrm{c}}$ CESBIO (CNES-CNRS-IRD-UPS), Toulouse, France
}

\begin{abstract}
The knowledge of evapotranspiration is of great interest in many applications such as assessing irrigation water use. In this paper, a methodology is present $\mathfrak{d}$ to, stimate evapotranspiration using the surface energy balance model S-SEBI (Simplified Surface Energy Balance Index) n $n$ the evaporative fraction. The method is applicable under the assumptions of constant atmospheric conditions and sufficier. wet and dry pixels over the image. The model uses remotely sensed parameters such as albedo, MSAVI (Modified Soil Adjusted Veg a a 'on Index) and surface temperature and emissivity images. The methodology has been applied over the Barrax test site. ' $心$ ' ted 1 the province of Albacete (Castilla La Mancha, Spain), in the framework of the DAISEX (Digital Airborne Imaging Spectruneter Experiment) campaigns carried out by ESA (European Space Agency). Net radiation, soil heat fluxes and evapotranspi . 110. have been obtained from DAIS images for alfalfa, corn and grass plots.

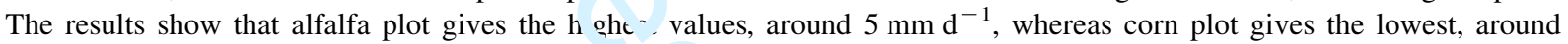
$3.5 \mathrm{~mm} \mathrm{~d}^{-1}$. The proposed methodology leading $\mathrm{t} \cdot \mathrm{n}$ i curacy for the daily evapotranspiration lower than $1 \mathrm{~mm} \mathrm{~d}^{-1}$.
\end{abstract}

(C) 2005 Elsevier B.V. All rights reserved.

Keywords: Evapotranspiration; Evaporative fraction; Net radiation flux; s il heat flux; DAIS; S-SEBI

\section{Introduction}

Evaporation is the process whereby liquid water is converted to water vapour and removed from the evaporating surface. Transpiration consists of the vaporisation of liquid water contained in plant tissues

\footnotetext{
* Corresponding author. Fax: +34 963543099.

E-mail addresses: sobrino@uv.es (J.A. Sobrino), monica. gomez@uv.es (M. Gómez), juancar.jimenez@uv.es (J.C. JiménezMuñoz), olioso@avignon.inra.fr (A. Olioso), ghani@cesbio.cnes.fr (G. Chehbouni).
}

and the vapour removal to the atmosphere. The $r$, min 'ination of the two separate processes whereby wa ${ }^{-}$. is lost on the one hand from the soil surface by er poration and on the other hand from the crop by tranupuratir $n$ is referred to as evapotranspiration (ET) (Allen $\left.-1 a^{1},{ }^{1} 998\right)$. Knowledge of crop evapotranspiration is $\mathrm{v} r \mathrm{y}: \mathrm{r}$ portant, because it allows optimisation of the irrigation rater use in arid and semi-arid regions where water sil age is a problem. The estimation of evapotranspira.un is of great importance for agricultural, hydrological and - $-11 \mathrm{r}$. 'tic studies, as it constitutes a major part of the nydrolc sical cycle. Conventional 
ground-based methods for estimating evapotranspiration such as the Bowen ratio, provide accurate measurements over a homogeneous area surrounding the instrument, but the results are not applicable to large diverse areas. Significant improvements are expected from mapping of the spatial distribution of evapotranspiration using remote sensing.

In this paper, a simple algorithm to estimate the evapotranspiration from DAIS (Digital Airborne Imaging Spectrometer) images is presented. The images were obtained in the framework of DAISEX (Digital Airborne Imaging Spectrometer Experiments) campaigns, a series of experiments supported by ESA (European Space Agency) and achieved in 1998 (DAISEX-98), 1999 (DAISEX-99) and 2000 (DAISEX-00) in Barrax $\left(39^{\circ} 3^{\prime} \mathrm{N}, 2^{\circ} 6^{\prime} \mathrm{W}\right)$, Castilla La Mancha (Spain). The description of the DAISEX campaigns and the DAIS sensor as well as the Barrax test site has been given below.

\section{Methodology}

On the basis of the S-SEBI (Simplified Surface Energy Balance Index) model developed by Roerink et al. (2000), the evapotranspiration (ET) can be estimated using the following equation

$\mathrm{LET}_{\mathrm{i}}=\Lambda\left(R_{\mathrm{ni}}-G_{\mathrm{i}}\right)$

where $\mathrm{LET}_{\mathrm{i}}$ is the instantaneous latent heat flux ( $\mathrm{W} \mathrm{m}^{-2}$ ), $\Lambda$ is the evaporative fraction, $R_{\mathrm{ni}}$ is the instantaneous net radiation flux ( $\mathrm{W} \mathrm{m}^{-2}$ ) and $G_{\mathrm{i}}$ is the instantaneous soil heat flux $\left(\mathrm{W} \mathrm{m}^{-2}\right)$. The methodology proposed in the paper is summarized in Fig. 1. Next, we give the expressions for the estimation of the different terms involved in Eq. (1).

\subsection{Net radiation flux}

The instantaneous net radiation flux can be obtained according to the following equation (Sobrino et al., 2000)

$$
R_{\mathrm{ni}}=(1-\alpha) R_{\mathrm{c} \lambda \downarrow}+\varepsilon R_{\mathrm{g} \lambda \downarrow}-\varepsilon \sigma T_{\mathrm{S}}^{4}
$$

where $\alpha$ is the albedo, $R_{\mathrm{c} \lambda \downarrow}$ is the incoming shortwave radiation $\left(\mathrm{W} \mathrm{m}^{-2}\right), R_{\mathrm{g} \lambda \downarrow}$ is the incoming longwave radiation $\left(\mathrm{W} \mathrm{m}^{-2}\right), \sigma$ is the Stefan Boltzman constant, $\varepsilon$ the surface emissivity, and $T_{\mathrm{S}}$ the surface temperature $(\mathrm{K})$. In order to estimate daily values,

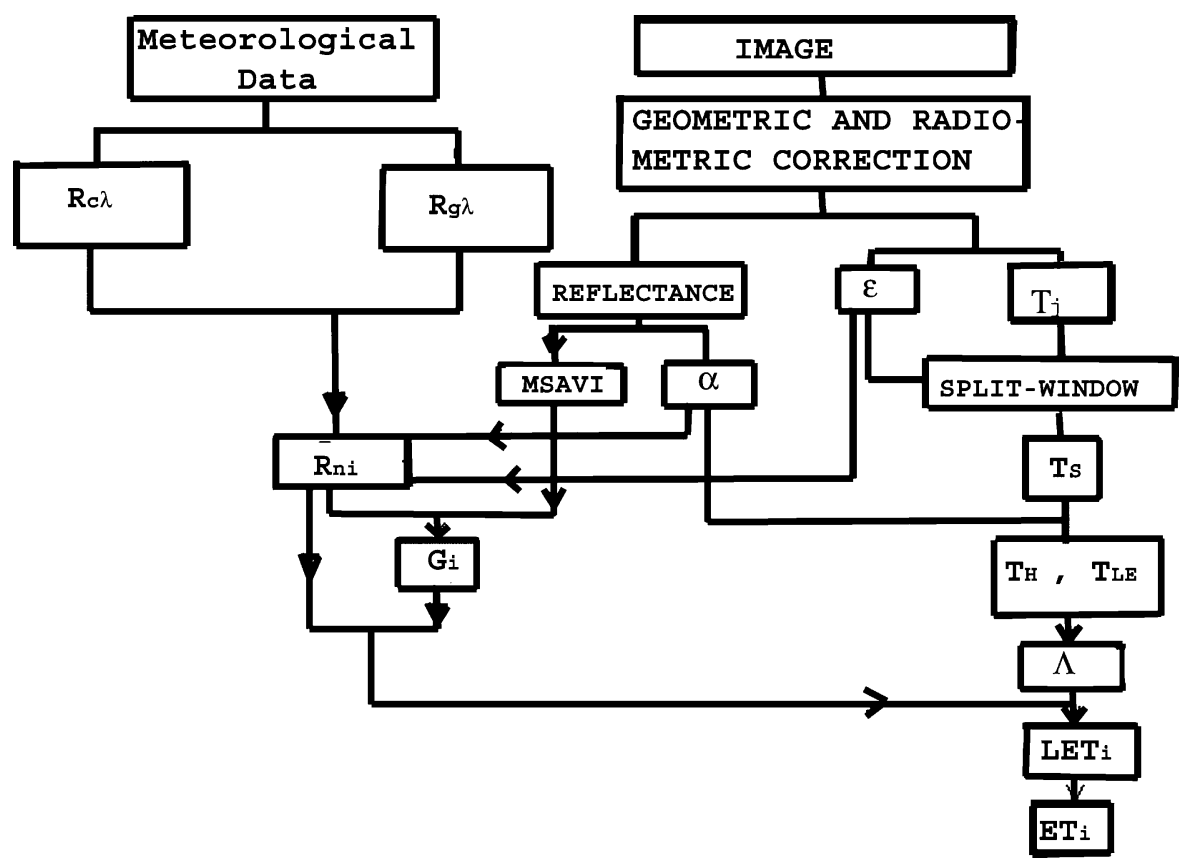

Fig. 1. Flowchart to obtain evapotranspiration. 
the procedure proposed by Seguin and Itier (1983) has been used. According to these authors the ratio between daily and instantaneous net radiation is constant for a given time. For example, at midday (12:00 solar time) in summer the following expression can be used:

$\frac{R_{\mathrm{nd}}}{R_{\mathrm{ni}}}=0.30 \pm 0.03$

For instantaneous values not acquired at midday in summer, the ratio between $R_{\mathrm{nd}}$ and $R_{\mathrm{ni}}$ needs to be recalculated (Wassenaar et al., 2002).

\subsubsection{Albedo}

The ratio of the solar radiative flux that is reflected from a surface to the flux intercepted by the surface is called albedo. According to Saunders (1990), the surface albedo has been calculated using the visible and near infrared (NIR) cha nels according to the following equation

$\alpha=\frac{1}{2}\left(\rho_{\mathrm{RED}}+\rho_{\mathrm{NIR}}\right)$

where $\rho_{\mathrm{RED}}$ and $\rho_{\mathrm{NIR}}$ are, resper'svely, the RED and NIR reflectances calculated in our case . .ng DAIS channels $10(0.66 \mu \mathrm{m})$ and $22\left(0.87 \mu^{r}\right.$, , esp ctively.

\subsubsection{Surface temperature and emissivity}

In order to apply Eq. (2), land surface L. mperature $\left(T_{\mathrm{S}}\right)$ and emissivity are needed. In this paper, $\mathrm{t}^{\mathrm{ie}} \mathrm{p} \mathrm{t} \mathrm{t}-$ window algorithm proposed by Sobrino et al. $\left(200^{4}\right.$, and adapted to DAIS channels has been used

$$
\begin{aligned}
T_{\mathrm{S}}= & T_{77}+2.937\left(T_{77}-T_{78}\right)+0.8193\left(T_{77}\right. \\
& \left.-T_{78}\right)^{2}-0.3284+(72.094-13.864 \mathrm{~W}) \\
& \times(1-\varepsilon)+(-119.592+25.136 \mathrm{~W}) \Delta \varepsilon
\end{aligned}
$$

where $T_{77}$ and $T_{78}$ are the at-sensor or brightness temperatures (in K) for DAIS thermal channels 77 and $78, \varepsilon=\left(\varepsilon_{77}+\varepsilon_{78}\right) / 2$ and $\Delta \varepsilon=\left(\varepsilon_{77}-\varepsilon_{78}\right)$ are the mean surface effective emissivity and the spectral emissivity difference, respectively, and $W$ is the total atmospheric water vapour content (in $\mathrm{g} \mathrm{cm}^{-2}$ ).

Land surface emissivity has been estimated from DAIS data using the NEM (Normalized Emissivity Method), developed by Gillespie (1985), following the procedure explained in Sobrino et al. (2004).
Despite the NEM is capable of providing $T_{\mathrm{S}}$, in this paper, we have obtained $T_{\mathrm{S}}$ from Eq. (5) which give better results specially for wet atmospheres (Sobrino and Jiménez-Muñoz, 2003). The accuracy of $T_{\mathrm{S}}$ and emissivity obtained from Eq. (5) and the NEM method is better than $1.5 \mathrm{~K}$ and 0.01 , respectively.

\subsection{Soil heat flux}

The soil heat flux can be estimated from the net radiation and the MSAVI (Modified Soil Adjusted Vegetation Index) values according to

$G_{\mathrm{i}}=R_{\mathrm{ni}} 0.5 \exp (-2.13 \mathrm{MSAVI})$

where MSAVI is given by (Qi et al., 1994):

MSAVI

$$
=\frac{2 \rho_{\mathrm{NIR}}+1-\sqrt{\left(2 \rho_{\mathrm{NIR}}+1\right)^{2}-8\left(\rho_{\mathrm{NIR}}-\rho_{\mathrm{RED}}\right)}}{2}
$$

As was explained before, $\rho_{\mathrm{RED}}$ and $\rho_{\mathrm{NIR}}$ are, respectively, the RED and NIR reflectances calculated using DAIS channels $10(0.66 \mu \mathrm{m})$ and $22(0.87 \mu \mathrm{m})$.

\subsection{Evaporative fraction}

According to Roerink et al. (2000), the evaporative fraction $(\Lambda)$ is given by

$$
\boldsymbol{\Lambda}=\frac{T_{\mathrm{H}}-T_{\mathrm{S}}}{T_{\mathrm{H}}-T_{\mathrm{LET}}}
$$

wh sre $T_{\mathrm{S}}$ is the land surface temperature and $T_{\mathrm{H}}$ and $\Lambda_{\text {LET }}$ are two temperatures obtained according to the , he ne given in Fig. 2. It should be noticed that $\mathrm{F}_{n}$. (8) is only applicable when the atmospheric cond dions are constant over the images and sufficient wet and $\Rightarrow$ pixels are present. From the analysis of the Fis. . Il 's observed an approximately constant surface ' $\mathrm{m}_{1} \cdot$ reture $\left(T_{\mathrm{S}}\right)$ for low albedo values. This concern wate satirrigated lanus. whr we all available energy is used in evaporation process. On the other hand, for higher albedo values the $f$ gure hows an increase of $T_{\mathrm{S}}$ with albedo. Thus, from $t$ to $B$ the temperature increases with albed ' 2 a'se of the change in the surface temperature is, res lt of the decrease of 


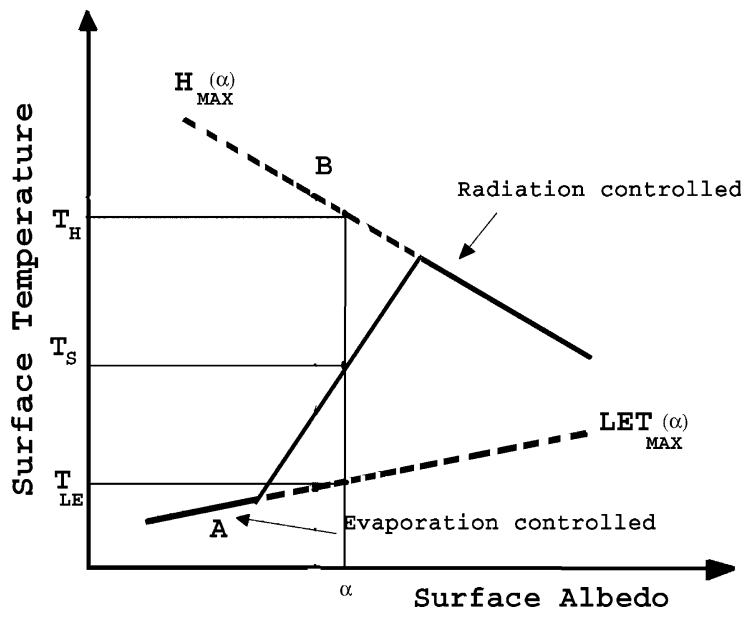

Fig. 2. Surface temperature versus surface albedo. $H$ is the sensible heat flux, LET is the latent heat flux and $\alpha$ is the albedo (adapted from Roerink et al., 2000).

the evaporation as a consequence of less soil moisture availability. Here, the sur ${ }^{r}$. ce $\iota$ mperature increase in excess due to sensible neat iux exceeds the decrease in net radiation due to the inc ads of albedo. Here, the surface temperature is said ' $\mathrm{co}^{r}$.rolled evaporation'. Finally, the surface temperatur (trum B) decreases with increasing albedo. This is due to the ret that soil moisture has decreased to such ar a xten that no evaporation can take place in this cios, and all available energy is used to heat the surf e. Thus to the increase of albedo, the available ener ' $\mathrm{y}$ ' -creases as a result of the decrease in net radiation. ', re, the

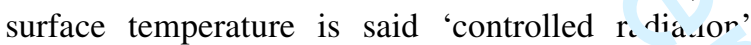
(Roerink et al., 2000). In this way, $T_{\mathrm{LET}}$ is $\mathrm{ob}^{+} .$. ned when $H_{\mathrm{i}}=0$, and therefore, $\mathrm{LET}_{\max } \mathrm{i}(\alpha)=R_{\mathrm{ni}}-G_{\mathrm{i}}$; and $T_{\mathrm{H}}$ when $\mathrm{LET}_{\mathrm{i}}=0$, and for this case, $H_{\max } \mathrm{i}(\alpha)=$ $R_{\mathrm{ni}}-G_{\mathrm{i}}$.

\subsection{Evapotranspiration}

Evapotranspiration can be easily obtained from Eq. (1) once the net radiation, the soil heat flux and the evaporative fraction are known. Estimation of evapotranspiration daily values $\mathrm{ET}_{\mathrm{d}}$ (in $\mathrm{mm} \mathrm{d}^{-1}$ ) requires the integration of the latent heat flux over the whole day, with $L$ the latent heat of vaporization $\left(2.45 \mathrm{MJ} \mathrm{kg}^{-1}\right)$. When LET values are instantaneous, as is the case of remote sensing images, then daily values can be obtained by assuming that the evaporative fraction at the daily scale is similar to the instantaneous value derived from Eq. (8) at the time of remote sensing data acquisition (Bastiaansen, 2000). In this way, writing Eq. (1) for daily and instantaneous values the following equation is obtained

$\frac{\mathrm{LET}_{\mathrm{d}}}{\mathrm{LET}_{\mathrm{i}}}=\frac{\Lambda_{\mathrm{d}}}{\Lambda_{\mathrm{i}}} \frac{\left(R_{\mathrm{nd}}-G_{\mathrm{d}}\right)}{\left(R_{\mathrm{ni}}-G_{\mathrm{i}}\right)} \approx \frac{\left(R_{\mathrm{nd}}-G_{\mathrm{d}}\right)}{\left(R_{\mathrm{ni}}-G_{\mathrm{i}}\right)}$

and therefore, it is possible to express daily values as a function of instantaneous values according to

$\mathrm{ET}_{\mathrm{d}}=\mathrm{LET}_{\mathrm{i}} \frac{R_{\mathrm{nd}}}{L\left(R_{\mathrm{ni}}-G_{\mathrm{i}}\right)}$

where the ground heat flux has been assumed close to rero at daily scale $\left(G_{\mathrm{d}} \approx 0\right)$ and daily net radiation can $b$ expressed in terms of instantaneous net radiation according to Eq. (3).

\section{3. " ne DAISEX field campaigns}

The lat scientific objective of the DAISEX campairns $\mathrm{N}^{\mathrm{s}} \mathrm{S}$ to demonstrate the feasibility of quantitative' $y$ ' 'trieving geo/biophysical variables by accountıng for atmospheric effects while at the same time analysing the data for possible additional information on dirf _tiona' anisotropy. Bio/geophysical variables incl tded to 2 leaf area index (LAI), biomass, leaf wate - . itert, canopy height, chlorophyll content, surface temr ratures and emissivity. 
Since, accurate calibration and atmospheric corrections are essential to quantitatively retrieve these variables, in situ atmospheric measurements (needed to derive the atmospheric corrections) were performed in addition to field measurements for validating calibration and retrieval. Three airborne campaigns were organised over test sites in Spain, France and Germany in 1998, 1999 and 2000 exploiting a range of different airborne instruments (Müller and Hausold, 2001).

\subsection{The DAIS sensor}

The Digital Airborne Imaging Spectrometer, DAIS 7915 (or simply DAIS), is a 79 channel high resolution optical spectrome ${ }^{+}$, which collects information from the Earth's s rfac ? in the $0.4-13 \mu \mathrm{m}$ wavelengths region while scanning from an aircraft, electronically processes this data into digital format consisting of 16 bit words, and arords these digital data on a cartridge recorde. The DAIS scan mechanism is a Kennedy type where a c s polygon mirror scans the terrain below thr $r_{\text {agl }}$ th $f$ opened window hatch in the bottom of the aircratt. The scan mirror rotates anti-clockwise with res $^{r} e^{t} t$ aircraft heading to provide a ground elt no 1 t r ross track scanning motion while the forward moti $n$ of $\mathrm{ie}$ aircraft provides a requested line-by-line sca... it most relevant geometric parameters are the $\mathrm{L} \cdot \mathrm{OV}$ (Instantaneous Field of View), $3.3 \mathrm{mrad}$, and the swath angle, $\pm 26^{\circ}$. From the 79 channels, six works in the $8-13 \mu \mathrm{m}$ region (from 74 to 79 , with the next effective wavelengths: 8.747, 9.648, 10.482, 11.266, 11.997 and $12.668 \mu \mathrm{m}$, respectively) with a bandwidth of $0.9 \mu \mathrm{m}$. They can be used for the retrieval of temperature and emissivity of land surface objects (Müller and Hausold, 2001). The principal characteristics of the DAIS sensor are shown in Table 1.

\subsection{The Barrax test site}

The Barrax test site is situated in the west of the province of Albacete, $28 \mathrm{~km}$ from the capital town $\left(39^{\circ} 3^{\prime} \mathrm{N}, 2^{\circ} 6^{\prime} \mathrm{W} ; 700 \mathrm{~m}\right.$ above sea level). The landscape in this area is flat with no change of elevation higher than $2 \mathrm{~m}$ over the whole area. Under Barrax area several aquiferous geological formations exit. These formations seem to be connected and form
Table 1

Principal characteristics for DAIS-7915 sensor

\begin{tabular}{lrll}
\hline \multicolumn{2}{l}{ Spectrometer characteristics } \\
$\begin{array}{l}\text { Wavelength } \\
\text { range (nm) }\end{array}$ & No. bands & Bandwidth & Detector \\
\hline $450-1050$ & 32 & $25 \mathrm{~nm}$ & $\mathrm{Si}$ \\
$1500-1800$ & 8 & $45 \mathrm{~nm}$ & $\mathrm{InSb}$ \\
$1900-2450$ & 32 & $25 \mathrm{~nm}$ & $\mathrm{InSb}$ \\
$3000-5000$ & 1 & $2.0 \mu \mathrm{m}$ & MCT \\
$8700-12300$ & 6 & $0.9 \mu \mathrm{m}$ & MCT \\
\hline
\end{tabular}

Geometric parameters

IFOV: $3.3 \mathrm{mrad}$

Swath angle: $\pm 26^{\circ}$

Image pixels per line: 512

Spatial Resolution: 2-20 m (depending on the flight altitude)

Radiometric parameters

Sensibility

VIS/NIR: NER $<0.25 \mathrm{~W} \mathrm{~m}^{-2} \mathrm{sr} \mu \mathrm{m}$ SWIR: NER $<0.25 \mathrm{~W} \mathrm{~m}^{-2} \mathrm{sr} \mu \mathrm{m}$ MIR/TIR: NET $<0.1 \mathrm{~K}$

Dynamic range: 15 bit

(no gain settings)

a regional groundwater body. The regional water table is about $20-30 \mathrm{~m}$ below the land surface. Nevertheless, there is some evidence that, at least locally, several perched aquifers exist with their water table between 4 and $7 \mathrm{~m}$ deep (Moreno et al., 2001).

The climate is of Mediterranean type, with heaviest ra tfalls in spring and autumn and lowest in summer. is presents a high level of continentally, with quite u'en changes from cold months to warm months an' 1 is hh thermal oscillations in all seasons between the $r$ aximum and minimum daily temperatures. The rairuall $\mathrm{s}^{-}$.istics show that the mean annual rainfall is little i.tor i. an $400 \mathrm{~mm}$ in most of the area, making La Mar sh sre of the driest regions in Europe. Precipitation ss sasonal, with minimum in summer and high year to year variability. The dominant cultivation in the 10,000 ha area is approximately $65 \%$ dry land (of $w^{\prime}$. 1 ch $07 \%$ are winter cereals and $33 \%$ fallow land) a id 35\% irrigated land (corn 75\%; barley/sunflower $15 \%$ dffalfa $5 \%$; onions $2.9 \%$; vegetables $2.1 \%$ ). The Uni ersity of Castilla-La Mancha, owns the agroc'. ${ }^{1}$ na ${ }^{+}$sogic station of Las Tiesas-Lisímetro $\left(39^{\circ} 03^{\prime} 3 \mathrm{C} \cdot \mathrm{N} \cdot 2^{\circ} 05^{\prime} 24^{\prime \prime} \mathrm{W}\right)$ in the study area of Barrax. 


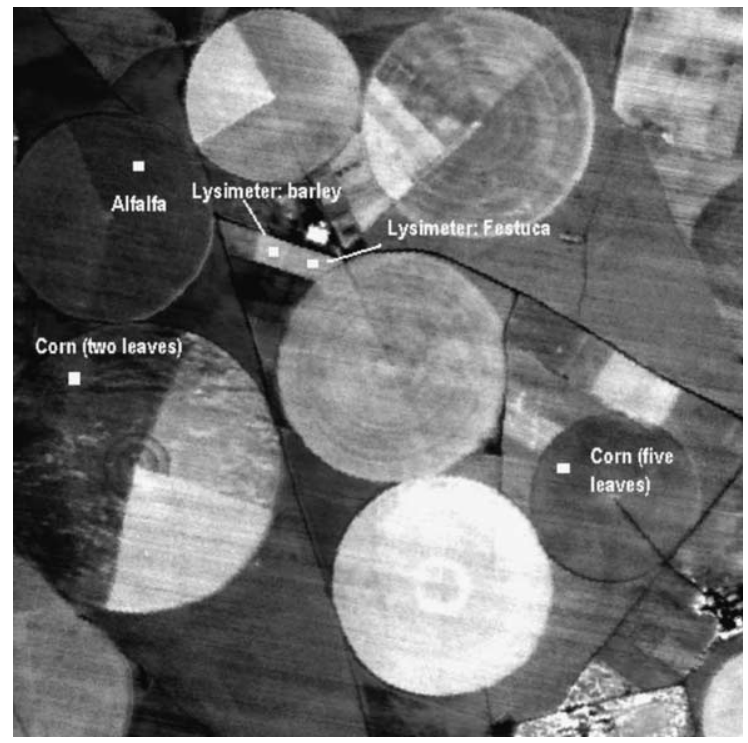

Fig. 3. DAIS image for the $\mathrm{Ba}^{r} \mathrm{x}$ - ite with the different plots selected to estimate evapotrar ${ }^{r}$,ir. tion.

Table 2

Meteorological data employed to dete nine the net radiation flux (where $R_{\mathrm{c} \lambda \downarrow}$; and $R_{\mathrm{g} \lambda \downarrow}$; are the incoming shortwa - nd longwave radiation, respectively)

\begin{tabular}{llll}
\hline Date & $\begin{array}{l}\text { Time flight } \\
(\mathrm{GMT})\end{array}$ & $\begin{array}{l}R_{\mathrm{c} \lambda \downarrow} \\
\left(\mathrm{W} \mathrm{m}^{-2}\right)\end{array}$ & $\begin{array}{l}R-1 \\
\left(\mathrm{~V} \mathrm{n}^{-2}\right)\end{array}$ \\
\hline June 3 & $12: 00$ & 1010 & $\vdots 4$ \\
& $12: 10$ & 1008 & 35. \\
June 4 & $8: 00$ & 548 & 318 \\
& $8: 10$ & 579 & 320 \\
& $15: 00$ & 797 & 357 \\
& $15: 10$ & 773 & 357 \\
\hline
\end{tabular}

\section{Results}

In order to analyse the results obtained by applying the methodology proposed, five regions of $5 \times 5$ pixels $\left(25 \mathrm{~m}^{2}\right)$ with different crops have been extracted from the DAIS images acquired over the Barrax test site: alfalfa, corn with five leaves, corn with two leaves, Festuca and barley (see Fig. 3). Table 2 shows the date and the time flight for the DAIS images used in this study, as well as the incoming shortwave and longwave radiation obtained from meteorological data and needed in order to estimate the net radiation from Eq. (2). Table 3 shows the $T_{\mathrm{H}}$ and $T_{\mathrm{LET}}$ values obtained for the different DAIS images as a function of surface albedo (see Section 2.3). Table 4 shows the results obtained for the different fluxes and the daily evapotranspiration by using the expressions explained in Section 2 and the data shown in Tables 2 and 3. And finally, Table 5 shows the instantaneous net radiation and soil heat fluxes measured in the Anchor Station, and the values estimated with the proposed method. The methodology has been tested using measured data from the lysimeter station located near the festuca and barley plots. The comparison between ET values obtained with the methodology proposed in the paper and the lysimeters measured values for 3 June 1999 on festuca $\left(5.01 \mathrm{~mm} \mathrm{~d}^{-1}\right)$ and barley $\left(5.35 \mathrm{~mm} \mathrm{~d}^{-1}\right)$ and for 4 June on festuca $\left(4.59 \mathrm{~mm} \mathrm{~d}^{-1}\right)$ and barley $\left(5.60 \mathrm{~mm} \mathrm{~d}^{-1}\right)$ shows a root mean square deviation (RMSD) of $1 \mathrm{~mm} \mathrm{~d}^{-1}$. Daily net radiation, daily latent heat and instantaneous heat soil and fluxes have been also compared with meteorological data, show1. g a RMSD of 7, 26 and 40\%, respectively. These $\therefore$ MSD values agree with the errors obtained from the . $u$. sitivity analysis (in which typical errors of 0.03 for

Table 3

Values of $T_{\mathrm{H}}$, and $T_{\mathrm{LET}}$ for the different flights as a function of albedo $(\alpha)$

\begin{tabular}{llll}
\hline Date & Time flight $(\mathrm{GMT})$ & $T_{\mathrm{H}}(\mathrm{K})$ & $T_{\mathrm{LET}}(\mathrm{K})$ \\
\hline $03 / 06 / 99$ & $12: 00$ & $-37.5 \alpha+3$, .0.0 & $17.5 \alpha+290.0$ \\
$04 / 06 / 99$ & $12: 10$ & $-55.0 \alpha+360$ & $12.5 \alpha+290.0$ \\
& $8: 00$ & $-32.5 \alpha+330.0$ & $10.0 \alpha+287.0$ \\
& $8: 10$ & $-40.0 \alpha+340.0$ & $7.5 \alpha+289.0$ \\
& $15: 00$ & $-32.5 \alpha+340.0$ & $17.5 \alpha+290.0$ \\
& $15: 10$ & $-35.0 \alpha+345.0$ & $17.5 \alpha+290.0$ \\
\hline
\end{tabular}

$T_{\mathrm{LET}}$ is obtained when $H_{\mathrm{i}}=0$, and therefore, $\mathrm{LET}_{\max \mathrm{i}}(\alpha)=R_{\mathrm{ni}}-G_{\mathrm{i}}$; and $T_{\mathrm{H}}$ when $\mathrm{LET}_{\mathrm{i}}=0$, anu Avi tr $\cdot$ case $H_{\operatorname{max~}}(\alpha)=R_{\mathrm{ni}}-\mathrm{G}_{\mathrm{i}}(\mathrm{see}$ Section 2.3). 
Table 4

Values of daily net radiation flux, $R_{\mathrm{nd}} / R_{\mathrm{n} \text {, }}$, instantaneous soil heat flux, evaporative fraction and daily evapotranspiration obtained from the proposed method and for the different plots extracted from DAIS images

\begin{tabular}{|c|c|c|c|c|c|c|}
\hline Plot & $\begin{array}{l}\text { Date/time flight } \\
\text { (GMT) }\end{array}$ & $R_{\mathrm{nd}} / R_{\mathrm{ni}}$ & $\begin{array}{l}R_{\mathrm{nd}} \\
\left(\mathrm{W} \mathrm{m}^{-2}\right)\end{array}$ & $\begin{array}{l}G_{\mathrm{i}} \\
\left(\mathrm{W} \mathrm{m}{ }^{-2}\right)\end{array}$ & $\Lambda$ & $\begin{array}{l}\mathrm{ET}_{\mathrm{d}}^{\mathrm{METHOD}} \\
\left(\mathrm{mm} \mathrm{d}^{-1}\right)\end{array}$ \\
\hline \multirow[t]{6}{*}{ Barley } & June 3/12:00 & 0.27 & 174.12 & 47.67 & 0.72 & 4.09 \\
\hline & June $3 / 12: 10$ & 0.27 & 157.88 & 43.89 & 0.70 & 3.60 \\
\hline & June 4/8:00 & 0.52 & 178.22 & 30.48 & 0.87 & 4.98 \\
\hline & June 4/8:10 & 0.49 & 175.62 & 32.14 & 0.89 & 5.02 \\
\hline & June 4/15:00 & 0.36 & 186.86 & 29.42 & 0.72 & 4.47 \\
\hline & June 4/15:10 & 0.38 & 185.45 & 29.16 & 0.73 & 4.49 \\
\hline \multirow[t]{6}{*}{ Festuca } & June 3/12:00 & 0.27 & 174.73 & 46.67 & 0.62 & 3.54 \\
\hline & June $3 / 12: 10$ & 0.27 & 169.81 & 44.48 & 0.71 & 3.95 \\
\hline & June 4/8:00 & 0.52 & 169.39 & 34.15 & 0.73 & 3.90 \\
\hline & June 4/8:10 & 0.49 & 166.64 & 35.82 & 0.76 & 4.00 \\
\hline & June 4/15:00 & 0.36 & 189.23 & 33.56 & 0.67 & 4.18 \\
\hline & June 4/15:10 & 0.38 & 186.80 & 32.16 & 0.67 & 4.12 \\
\hline \multirow[t]{6}{*}{ Alfalfa } & June $3 / 12: 00$ & 0.27 & 159.10 & 15.37 & 0.88 & 4.81 \\
\hline & June $3 / 12: 10$ & 0.27 & 152.36 & 14.56 & 0.91 & 4.76 \\
\hline & June 4/8:00 & 0.52 & 147.26 & 10.83 & 0.96 & 4.79 \\
\hline & June 4/8:10 & 0.49 & 150.81 & 11.41 & 0.96 & 4.91 \\
\hline & June 4/15:00 & 0.36 & 173.41 & 10.86 & 0.91 & 5.44 \\
\hline & June 4/15:10 & 0.38 & 173.67 & 10.63 & 0.92 & 5.50 \\
\hline Corn & June 3/12:00 & 0.27 & 159.09 & 61.37 & 0.76 & 3.82 \\
\hline \multirow[t]{5}{*}{ (two leaves) } & June $3 / 12: 10$ & 0.27 & 150.49 & 58.59 & 0.76 & 3.61 \\
\hline & June 4/8:00 & 0.52 & 154.56 & 50.94 & 0.78 & 3.52 \\
\hline & June 4/8:10 & 0.49 & 143.19 & 48.10 & 0.80 & 3.37 \\
\hline & June 4/15:00 & 0.36 & 131.92 & 31.47 & 0.51 & 2.17 \\
\hline & June $4 / 15: 10$ & 0.38 & 144.65 & 36.11 & 0.60 & 2.77 \\
\hline \multirow{6}{*}{$\begin{array}{l}\text { Corn } \\
\text { (five leaves) }\end{array}$} & June 3/12:00 & 0.27 & 161.39 & 63.11 & 0.70 & 3.56 \\
\hline & June $3 / 12: 10$ & 0.27 & 159.66 & 63.00 & 0.76 & 3.82 \\
\hline & June 4/8:00 & 0.52 & 143.61 & 47.69 & 0.74 & 3.10 \\
\hline & June 4/8:10 & 0.49 & 149.84 & 47.67 & 0.78 & 3.43 \\
\hline & June 4/15:00 & 0.36 & 159.43 & 43.89 & 0.56 & 2.85 \\
\hline & June 4/15:10 & 0.38 & 152.44 & 30.48 & 0.58 & 2.81 \\
\hline
\end{tabular}

albedo, $1.5 \mathrm{~K}$ for temperature, 0.01 for emissivity and $5 \%$ for the incoming shortwave and longwave radiation have been considered).

Once the algorithm have been evaluated, it has been applied to DAIS images. Figs. 4 and 5 show, respectively, the daily evapotranspiration obtained from 4 June at 8:00 GMT on the Barrax site and the difference between daily evapotranspiration estimated for two consecutive flights. Fig. 4 shows the highest values for alfalfa and lowest values for corn plots and allows to distinguish the irrigated areas on the different plots. Fig. 5 shows little differences between the two consecutive flights, which gives some confidence on the developed methodology to obtain the evapotranspiration.
Table 5

Experimental and model values of $R_{\mathrm{ni}}$ and $G_{\mathrm{i}}$ for the Barrax test site

\begin{tabular}{|c|c|c|c|c|}
\hline \multirow{2}{*}{$\begin{array}{l}\text { Date/time } \\
\text { flight } \\
\text { (GMT) }\end{array}$} & \multicolumn{2}{|l|}{ Method } & \multicolumn{2}{|c|}{ Anchor station measure } \\
\hline & $\begin{array}{l}R_{\mathrm{ni}} \\
\left(\mathrm{W} \mathrm{m}{ }^{-2}\right)\end{array}$ & $\begin{array}{l}\mathrm{G}_{\mathrm{i}} \\
\left(\mathrm{W} \mathrm{m} \mathrm{m}^{-2}\right)\end{array}$ & $\begin{array}{l}R_{\mathrm{ni}} \\
\left(\mathrm{W} \mathrm{m}{ }^{-2}\right)\end{array}$ & $\begin{array}{l}G_{\mathrm{i}} \\
\left(\mathrm{W} \mathrm{m}{ }^{-2}\right)\end{array}$ \\
\hline June 3/12:00 & 464.0 & 53.5 & 570.0 & 54.0 \\
\hline June 3/12:10 & 498.4 & 54.6 & 567.0 & 54.0 \\
\hline June 4/8:00 & 315.7 & 67.2 & 277.0 & 13.0 \\
\hline June $4 / 8: 10$ & 296.0 & 50.3 & 297.0 & 16.0 \\
\hline June 4/15:00 & 333.6 & 32.4 & 400.0 & 48.0 \\
\hline June 4/15:10 & 364.0 & 40.9 & 384.0 & 46.0 \\
\hline
\end{tabular}




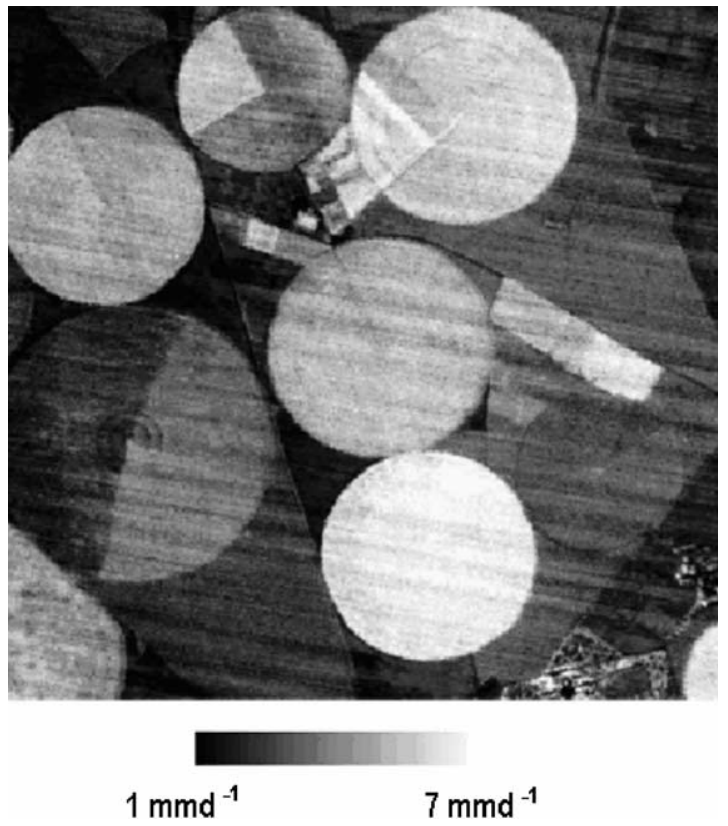

Fig. 4. Daily evapotranspiration $\left(\mathrm{ET}_{\mathrm{d}}\right)$ image obtained from DAIS image on June 4th at 8:00 GMT.

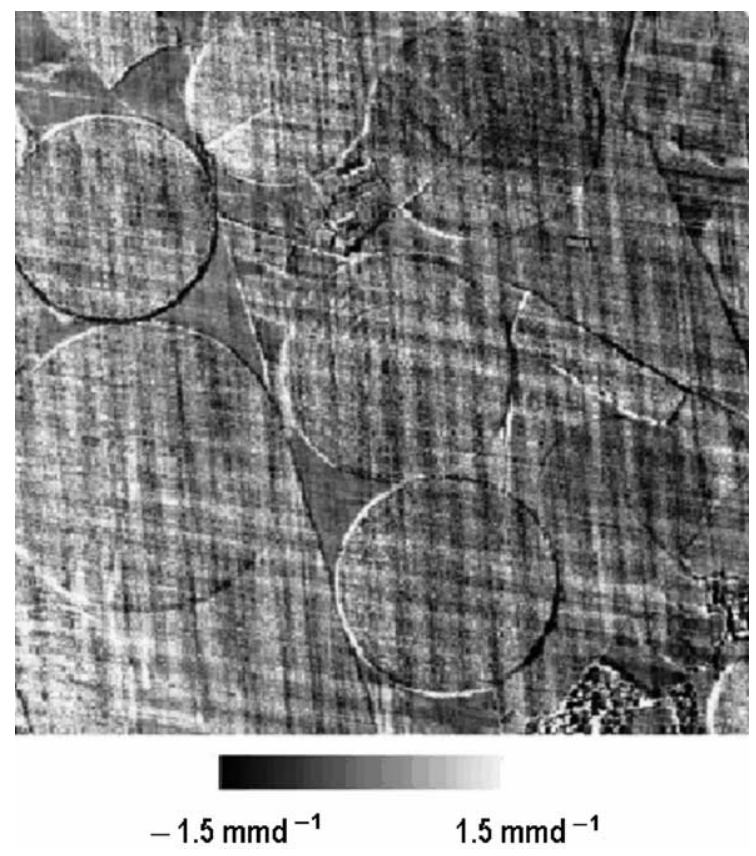

Fig. 5. Difference between daily evapotranspiration $\left(\mathrm{ET}_{\mathrm{d}}\right)$ obtained from DAIS images on June 4th at 8:00 and 8:10 GMT.

\section{Conclusions}

In this paper, a simplified methodology in order to obtain daily evapotranspiration. The methodology has been applied to an experimental test site in Albacete (Spain) in which five plots have been selected (alfalfa, corn with two and five leaves, festuca and barley). The results show daily evapotranspiration can be obtained with an error lower than $1 \mathrm{~mm} \mathrm{~d}^{-1}$. The main disadvantage of the methodology proposed is the requirement of extreme surface values over the image. Other methods as SEBAL shows better results in the daily evapotranspiration determination, but this method includes the determination of the roughness length, which is a difficult task. Further, studies are necessary in order to confirm the results presented in this paper.

\section{Acknowledgements}

We wish to thank the ESA (European Space Agency) for financial support (projects ESA-ESTEC 13053/NL/GD and 13390/NL/GD) and the DLR (German Optoelectronic Institute) for providing the DAIS images. We would also like to thank the European Union (EAGLE, Project SST3-CT-2003502057) and the Ministerio de Ciencia y Tecnología (project REN2001-3105/CLI) for the financial support.

\section{References}

Allen, R.G., Pereira, L.S., Raes, D., Smith, M., 1998. Crop evapotranspiration-Guidelines for computing crop water requirements. FAO Irrigation and drainage paper 56, Rome.

Bastiaanssen, W.G.M., 2000. SEBAL-based sensible and latent heat fluxes in the irrigated Gediz Basin, Turkey. J. Hydrol. 229, $87-100$.

Gillespie, A.R., 1985. Lhitologic mapping of silicate rocks using TIMS. The TIMS Data Users Workshop. JPL Publications pp. 86-38, see also 29-44.

Moreno, J., Calera, A., Caselles, V., Cisneros, J.M., Martinez-Lozano, J.A., Melia, J., Montero, F., Sobrino, J.A., 2001. The measurement programme at Barrax. DAISEX Final Results Workshop, ESTEC, Holland, 15-16 March 2001, ESA SP-499, pp. 43-51.

Müller, A., Hausold, A., 2001. The airborne imaging spectrometer data acquisition programme in 1998, 1999 and 2000. DAISEX Final Results Workshop, ESTEC, Holland, 15-16 March 2001, ESA SP-499, pp. 7-11. 
Qi, J., Chehbouni, A., Huete, A.R., Kerr, Y.H., Sorooshian, S., 1994. A modified soil adjusted vegetation index (MSAVI). Remote Sensing Environ. 48, 119-126.

Roerink, G.J., Su, Z., Menenti, M., 2000. S-SEBI: a simple remote sensing algorithm to estimate the surface energy balance. Phys. Chem. Earth (B) 25 (2), 147-157.

Saunders, R.W., 1990. The determination of broad land surface albedo from AVHRR visible and near infrared radiances. Int. J. Remote Sensing 11, 49-67.

Seguin, B., Itier, B., 1983. Using midday surface temperature to estimate daily evaporation from satellite thermal IR data. Int. J. Remote Sensing 4 (2), 371-383.

Sobrino, J.A., Jiménez-Muñoz, J.C., 2003. Land surface temperature retrieval in the framework of the SPECTRA mission, Proceedings of Second SPECTRA Workshop, 28-30 October, STEC (Noordwijk, The Netherlands). ESA Publications.
Sobrino, J.A., Raissouni, N., Kerr, Y., Olioso, A., LópezGarcía, M.J., Belaid, A., El Kharraz, J., Cuenca, J., Dempere, L., 2000. In: Sobrino, J.A. (Ed.), Teledetección. Servicio de publicaciones, Universidad de Valencia, Valencia, Spain. ISBN: 84-37034220-8.

Sobrino, J.A., Jiménez-Muñoz, J.C., El Kharraz, J., Gomez, M., Romaguera, M., Soria, G., 2004. Single-channel and twochannel methods for land surface temperature retrieval from DAIS data and its application to the Barrax site. Int. J. Remote Sensing 25 (1), 215-230.

Wassennar, T., Olioso, A., Hasager, C., Jacob, F., Chehbouni, A., 2002. Estimation of evapotranspiration on heterogeneous pixels. In: Sobrino, J.A. (Ed.), First International Symposium on Recent Advances in Quantitative Remote Sensing, 16-20 September 2002. Publicacions de la Universitat de València, España, Valencia, Spain, pp. 458-465. 